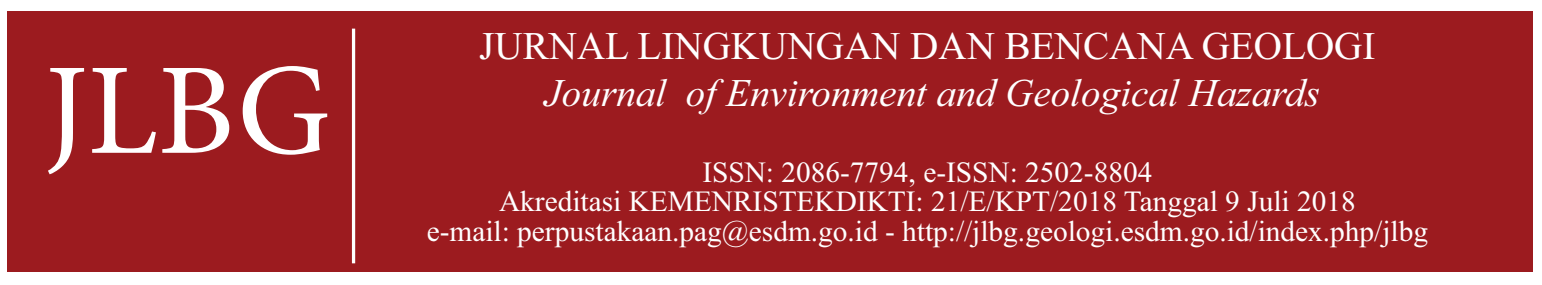

\title{
Karakteristik Keteknikan Sedimen Kuarter Kaitannya dengan Potensi Bahaya Geologi di Kawasan DAS Cimanuk Bagian Hilir
}

\section{Engineering Characteristics of Quaternary Sediment Related to Potential Geological Hazards in the Lower Cimanuk Catchment Area}

\author{
Rifki Asrul Sani ${ }^{1}$, Eko Soebowo ${ }^{2}$, Armein M. Fikri ${ }^{1}$ dan Imam A. Sadisun ${ }^{1}$ \\ ${ }^{1}$ Program Studi Teknik Geologi Institut Teknologi Bandung \\ ${ }^{2}$ Pusat Geoteknologi LIPI Bandung \\ e-mail: kang.sani.geologi@gmail.com \\ Naskah diterima 10 November 2019, selesai direvisi 11 Desember 2020, dan disetujui 15 Desember 2020
}

\begin{abstract}
ABSTRAK
Kabupaten Indramayu yang akan dikembangkan sebagai kawasan industri didominasi oleh endapan Kuarter yang terdiri atas endapan fluvial, dataran banjir, pematang pantai, dan delta. Daerah tersebut terletak pada area dekat sesar aktif, yakni segmen sesar Baribis-Subang dengan besaran magnitudo 6,5 Mw. Penelitian di wilayah DAS Cimanuk bagian hilir Kabupaten Indramayu, Provinsi Jawa Barat bertujuan untuk mengetahui karakteristik fisik dan mekanik serta kaitannya dengan potensi bahaya geologi yang bisa terjadi. Metode yang digunakan dalam penelitian ini adalah pengamatan 4 inti bor teknik dan pola kurva sondir (10 CPTu dan $13 \mathrm{CPT})$ serta analisis laboratorium yakni ukuran butir, hydrometer, batas-batas Atterberg, dan klasifikasi sedimen. Berdasarkan pengamatan inti bor, pola kurva sondir, dan analisis laboratorium, jenis sedimen yang berkembang di daerah penelitian adalah lempung, lanau, lanau pasiran, pasir lanauan dan pasir dengan karakteristik yang spesifik. Tingkat kepadatan sedimen pasir serta tingkat konsistensi sedimen lempung bagian utara penelitian menunjukkan karakteristik yang relatif lebih lepas dan lunak dibandingkan dengan bagian selatan. Berdasarkan karakteristik keteknikan menunjukkan bahwa nilai N-SPT $<10$ atau CPT/CPTu $<6.000 \mathrm{kPa}$ pada sedimen pasir dan pasiran berpotensi terhadap likuefaksi dan nilai N-SPT $<4$ atau CPT/CPTu $<$ $5.000 \mathrm{kPa}$ pada sedimen lempung dan lanau berpotensi terhadap amblesan.
\end{abstract}

Kata kunci: bahaya geologi, Cimanuk, sedimen kuarter

\section{ABSTRACT}

As a future industrial area, Indramayu Regency is dominated by Quaternary sediment of fluvial, flood plain, beach ridge and deltaic sediments. The area is close to active faults, The Baribis-Subang fault segment with 6.5 Mw. This research is conducted around the lower Cimanuk catchment of Indramayu. Its aims to determine mechanical and physical characteristics related to potential geological hazards. The methods used in this research are 4 core observation, cone penetration patterns (10 CPTu and 13 CPT) and laboratory analysis such as grain size, hydrometer, Atterberg limits and sediment classification. Based on its methods, sediments that develop at the research area are clay, silt, sandy silt, silty sand and sand with specific character. Level consistency and density of clay and sand at the northern area is relatively soft and loose than the southern one. Based on engineering characteristics, the results show that $N$ $S P T<10$ or $C P T / C P T u<6,000 \mathrm{kPa}$ value of sandy and sand sediment are potential against liquefaction and N-SPT $<4$ or $C P T / C P T u<5,000 \mathrm{kPa}$ value of silt and clay sediment are potential against subsidence.

Keywords: geological hazards, Cimanuk, quarternary sediment

\section{PENDAHULUAN}

Berdasarkan Peraturan Pemerintah Nomor 14 Tahun 2015 tentang Rencana Induk Pembangunan Industri Nasional (RIPIN) tahun 2015-
2035, daerah Indramayu termasuk ke dalam Wilayah Pusat Pertumbuhan Industri (WPPI) di Jawa Barat yang akan dikembangkan menjadi kawasan industri. Dalam hal ini, pengetahuan 
mengenai kondisi geologi dan geologi teknik akan membantu dalam penentuan kawasan terbaik serta mengurangi risiko akibat bencana geologi maupun kegagalan infrastruktur.

Hasil riset dan studi Pusat Gempa Nasional tahun 2017 menyebutkan bahwa wilayah Indramayu berada pada tiga segmen sesar aktif yang berdekatan. Ketiga segmen sesar aktif tersebut dapat menimbulkan gempa dengan besaran masing-masing segmen, antara lain segmen Sesar Subang dengan skala 6,5 Mw, segmen Sesar Cirebon 1 dengan skala 6,2 $M w$, dan segmen Sesar Cirebon 2 dengan skala 6,5 Mw (Irsyam drr, 2017). Indramayu juga termasuk ke dalam zona dengan tingkat kerentanan sedang terhadap bahaya geologi berupa likuefaksi (Buana drr., 2019). Daerah Eretan dan Losarang yang merupakan bagian dari wilayah Kabupaten Indramayu memiliki tingkat kerentanan sangat rendah sampai tinggi terhadap bahaya likuefaksi (Batu dan Hidayat, 2011). Demikian pula, seperti umumnya kota- kota besar di Indonesia yang tidak luput dari ancaman amblesan tanah, wilayah perkotaan di pesisir Jawa Utara seperti Jakarta (Abidin drr., 2008), Indramayu (Andreas drr., 2017), Semarang (Abidin drr., 2013), Surabaya (Kurniawan, 2011), mengalami amblesan tanah dengan laju 1 - $>10 \mathrm{~cm} /$ tahun.

Mengacu pada penelitian terkait kondisi geologi dan geologi teknik permukaan dan bawah permukaan daerah Indramayu semisal Tjia drr. (1968), Bird dan Ongkosongo (1980), Batu dan Hidayat (2011) dan Setyawan (2017), penelitian ini akan memberikan gambaran yang lebih komprehensif dan membantu dalam hal pengembangan kawasan industri di daerah Indramayu dan sekitarnya.

Secara geologi, Kabupaten Indramayu dan sekitarnya (Gambar 1) disusun oleh sedimen Kuarter yang berumur Plistosen - Holosen, terdiri dari batupasir tufan dan konglomeratan, endapan dataran banjir, endapan sungai muda, endapan pematang pantai, endapan pantai, dan endapan

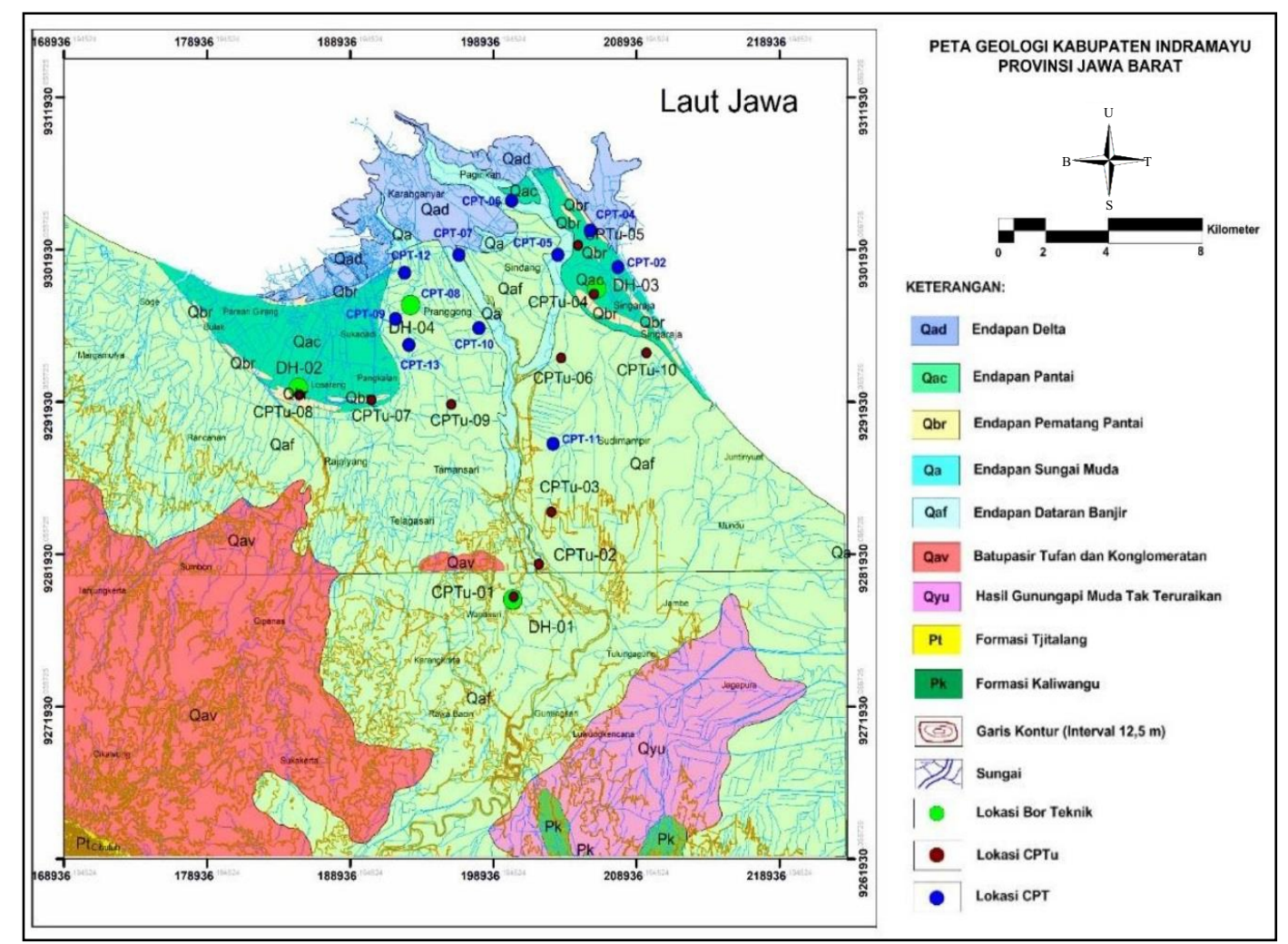

Gambar 1. Peta Geologi Kabupaten Indramayu (digambar ulang dari Peta Geologi Lembar Arjawinangun (Djuri, 1973) dan Peta Geologi Lembar Indramayu (Achdan dan Sudana, 1992)) dan lokasi pengujian teknik. 
delta (Djuri, 1973; Achdan dan Sudana, 1992). Endapan dataran banjir menempati wilayah terluas dibandingkan sedimen yang lainnya $( \pm 70 \%$ ) berupa lempung pasiran dan pasir lempungan (sebagian tufan). Dengan mempertimbangkan kondisi geologi berupa sedimen Kuarter yang belum terkonsolidasi dan berada pada daerah rawan guncangan gempa, maka pengetahuan mengenai karakterisitik geologi teknik bawah permukaan penting untuk diketahui (Soebowo, 2016).

Cimanuk, yang juga melalui Indramayu, merupakan salah satu sungai dengan pertumbuhan delta yang tinggi di Pulau Jawa (Tjia drr., 1968; Bird dan Ongkosongo, 1980). Rata-rata laju pertumbuhan dalam kurun waktu tahun 1857 - 1946 pada daerah Indramayu sebesar 204 m, yakni proses sedimentasi yang berasal dari $\mathrm{Su}-$ ngai Cimanuk, Rambatan, Anjar, dan Tjemoro. Gambar 2.a menunjukkan pertumbuhan garis pantai Delta Cimanuk, perkembangan garis pantai yang semakin cepat (progresif) ke arah utara menunjukkan suplai sedimen dari arah hulu (selatan) yang sangat besar. Delta Cimanuk memiliki relief datar dan berelevasi rendah.
Delta ini terbentuk sebagai hasil pengendapan sedimen yang dibawa oleh aliran Cimanuk dan diendapkan di Laut Jawa. Material sedimen penyusun endapan delta didominasi sedimen berukuran lempung (Setyawan, 2017). Hal itu terlihat dari data pengeboran (Gambar 2.b) yang diperoleh dari Desa Brondong (wilayah utara Indramayu yang termasuk Kecamatan Sindang).

Uji penetrasi standar (SPT) digunakan untuk mengetahui sifat-sifat fisik sedimen di lapangan (SNI 4153:2008) (Gambar 3). SPT dilakukan dengan memukul sebuah tabung standar ke dasar lubang bor sedalam $45 \mathrm{~cm}$ dengan palu seberat $63,5 \mathrm{~kg}$ yang jatuh bebas dengan ketinggian 76 $\mathrm{cm}$. Jumlah pukulan yang dibutuhkan untuk penetrasi setiap $15 \mathrm{~cm}$ dicatat, kecuali untuk $15 \mathrm{~cm}$ pertama. Jumlah penetrasi atau pukulan $30 \mathrm{~cm}$ terakhir dicatat sebagai nilai $\mathrm{N}$ ( $\mathrm{N}$-value) yang kemudian dikorelasikan dengan tingkat kepadatan relatifnya berdasarkan Wesley (2011) untuk sedimen berbutir kasar serta konsistensi berdasarkan Terzaghi drr. (1996) untuk sedimen berbutir halus (Tabel 1).

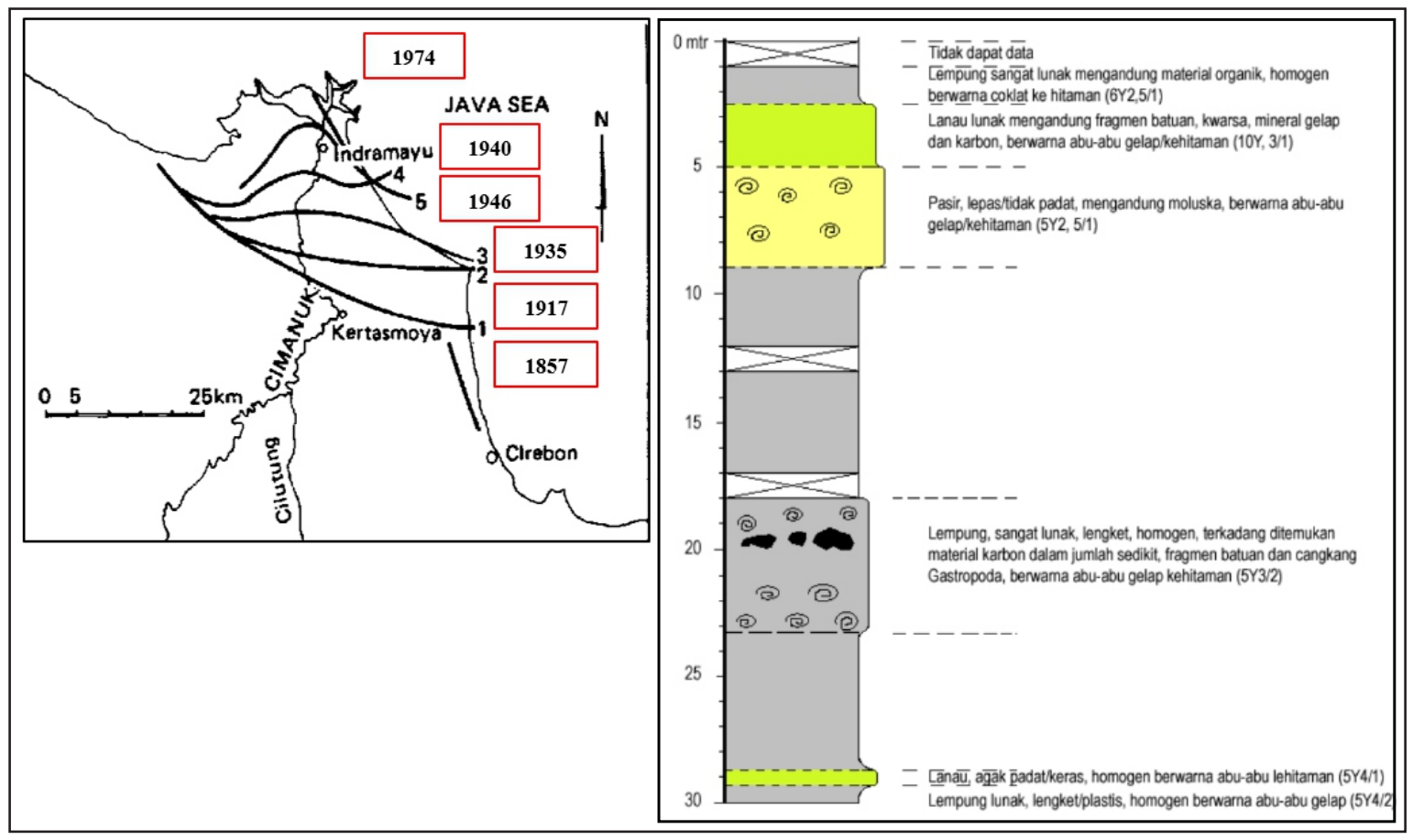

Gambar 2. a. Perkembangan garis pantai Delta Cimanuk dari tahun 1857 sampai 1974 (modifikasi dari Bird dan Ongkosongo, 1980); b. Litologi penyusun Delta Cimanuk dari Desa Brondong (PPPGL, 2016 dalam Setyawan, 2017). 


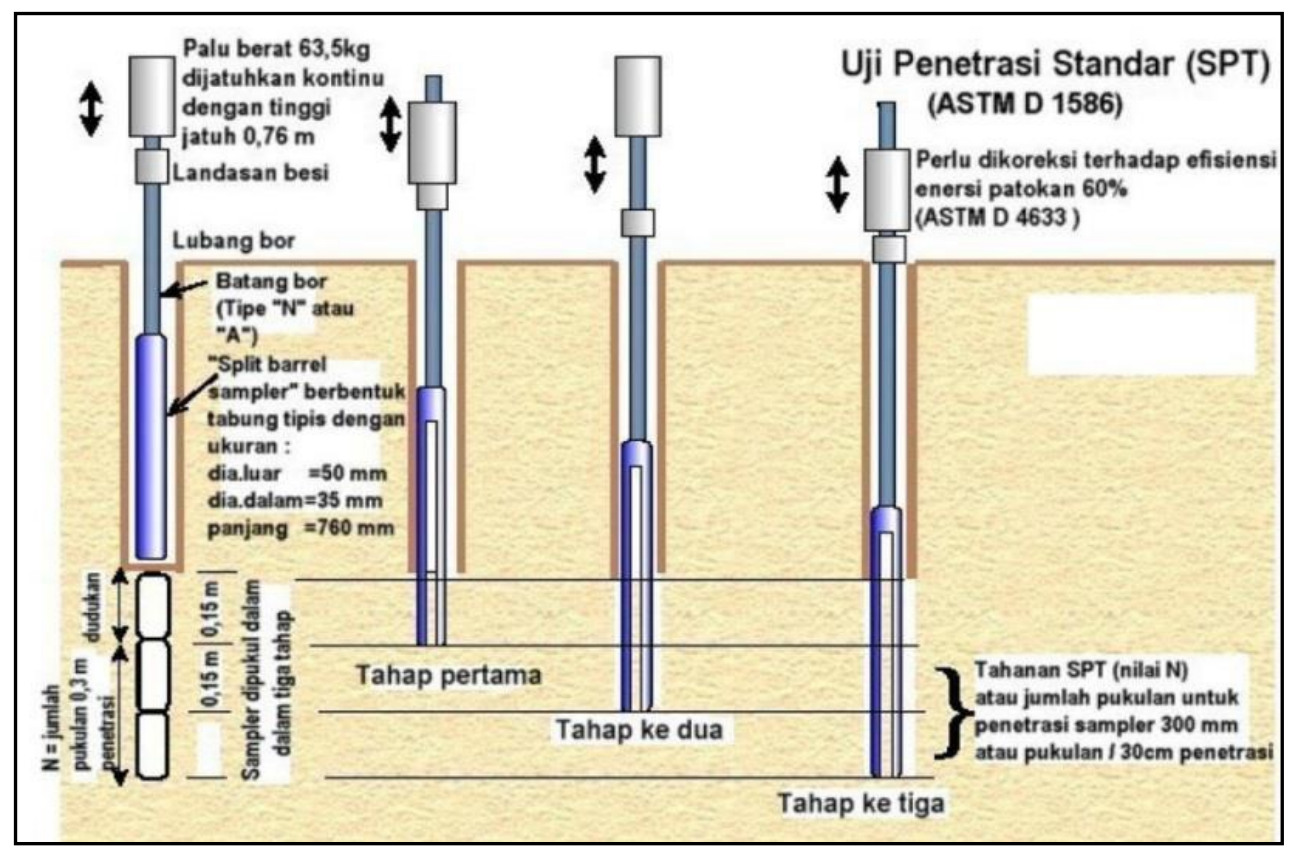

Gambar 3. Skema urutan uji penetrasi standar (SPT) (SNI 4153:2008).

Tabel 1. Hubungan tingkat kepadatan sedimen berbutir kasar (Wesley, 2011) serta konsistensi sedimen berbutir halus (Terzaghi drr., 1996) terhadap nilai N-SPT atau CPT.

\begin{tabular}{|cccc|}
\hline Tingkat Kepadatan & N-SPT/CPT $(\mathbf{M P a})$ & Konsistensi & N-SPT/CPT (MPa) \\
\hline Sangat padat & $>50 />20$ & Keras & $>30 / 0,4$ \\
\hline Padat & $30-50 / 12-20$ & Sangat kaku & $15-30 / 0,2-0,4$ \\
\hline Agak padat & $10-30 / 4-12$ & Kaku & $8-15 / 0,1-0,2$ \\
\hline Lepas & $4-10 / 2-4$ & Sedang & $4-8 / 0,05-0,1$ \\
\hline Sangat lepas & $<4 /<2$ & Lunak & $2-4 / 0,025-0,05$ \\
\hline & & Sangat lunak & $<2 /<0,025$ \\
\hline
\end{tabular}

CPT merupakan metode yang digunakan untuk menentukan sifat-sifat geoteknik sedimen dan menggambarkan stratigrafi sedimen (Lunne drr., 1997) (Gambar 4.a). CPT merupakan alat utama yang banyak dipakai untuk kegiatan investigasi geoteknik (Bell, 2007). Beberapa alat atau sensor dapat dipasang di CPT, salah satunya adalah sensor ' $u$ ' atau sensor untuk mengukur tekanan air pori (CPTu) (Gambar 4.b). Metode CPTu terdiri dari instrumentasi konus yang ujungnya menghadap ke bawah dengan panjang $\pm 30 \mathrm{~cm}$, luas penampang $10 \mathrm{~cm}^{2}$ serta dilengkapi alat pengukur hambatan lekat dan air pori (Wesley, 1977). Dalam penggunaannya, konus akan ditekan ke dalam tanah dengan kecepatan 1,5 - 2,5 $\mathrm{cm} /$ detik (Lunne drr., 1997). CPTu secara standar akan mengukur beberapa parameter yakni; hambatan ujung $(q c)$, kekuatan yang dibutuhkan untuk menembus sedimen; hambatan lekat $(f s)$, kekuatan yang dihasilkan di sisi konus ketika bergerak; tekanan pori $(u)$, tekanan air yang dihasilkan ketika konus bergerak melalui sedimen; dan persentasi kandungan fraksi halus (FC), digunakan untuk interpretasi litologi.

Sama halnya dengan uji SPT, nilai hambatan ujung/konus $(q c)$ kemudian dikorelasikan dengan tingkat kepadatan berdasarkan Wesley (2011) untuk sedimen berbutir kasar serta konsistensi berdasarkan Terzaghi drr. (1996) untuk sedimen berbutir halus. Uji CPT membantu dalam interpretasi jenis sedimen melalui karakterisasi ukuran butir (Robertson, 1998). Nilai hambatan ujung atau tahanan konus $(q c)$ disebandingkan dengan hambatan lekat atau tahanan gesek $(f s)$ akan menghasilkan indeks perilaku jenis tanah $\left(I_{c}\right)$ (Tabel 2 dan Gambar 5). 


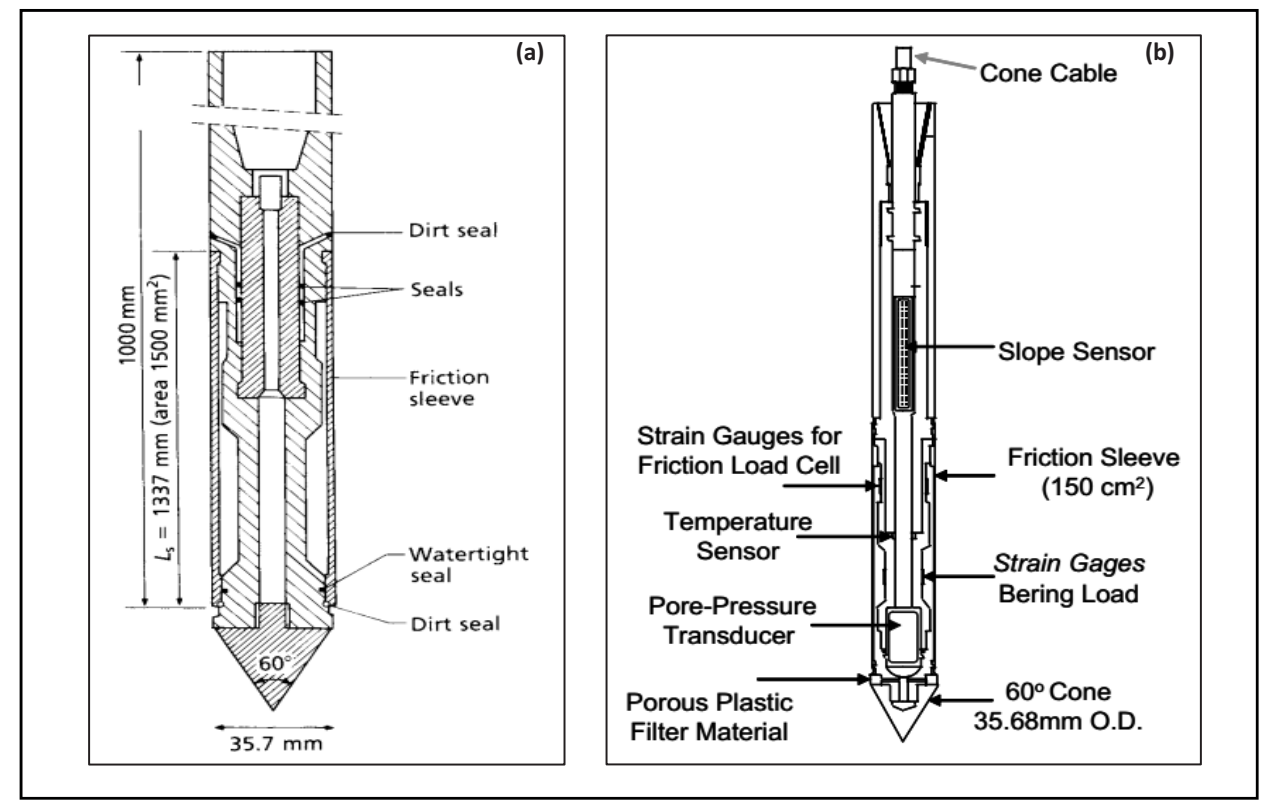

Gambar 4. Rangkaian alat sondir: a) CPT (Bell, 2007) dan b) CPTu (Davies dan Campanella, 1995).

Tabel 2. Indeks perilaku jenis tanah (Ic) berdasarkan data uji CPT (Robertson dan Wride, 1998).

\begin{tabular}{|ccl|}
\hline Indeks perilaku jenis tanah $\left(\boldsymbol{I}_{\mathbf{c}}\right)$ & Zona (Gambar 4) & Jenis tanah \\
\hline$I<1,31$ & 7 & Pasir kerikilan - pasir padat \\
\hline $1,31<I<2,05$ & 6 & Pasir - pasir lanauan \\
\hline $2,05<I<2,60$ & 5 & Pasir campuran: pasir lanauan - lanau pasiran \\
\hline $2,60<I<2,95$ & 4 & Lanau campuran: lanau lempungan - lempung lanauan \\
\hline $2,95<I<3,60$ & 3 & Lempung: lempung lanauan - lempung \\
\hline$I_{c}>3,60$ & 2 & Tanah organik: gambut \\
\hline
\end{tabular}

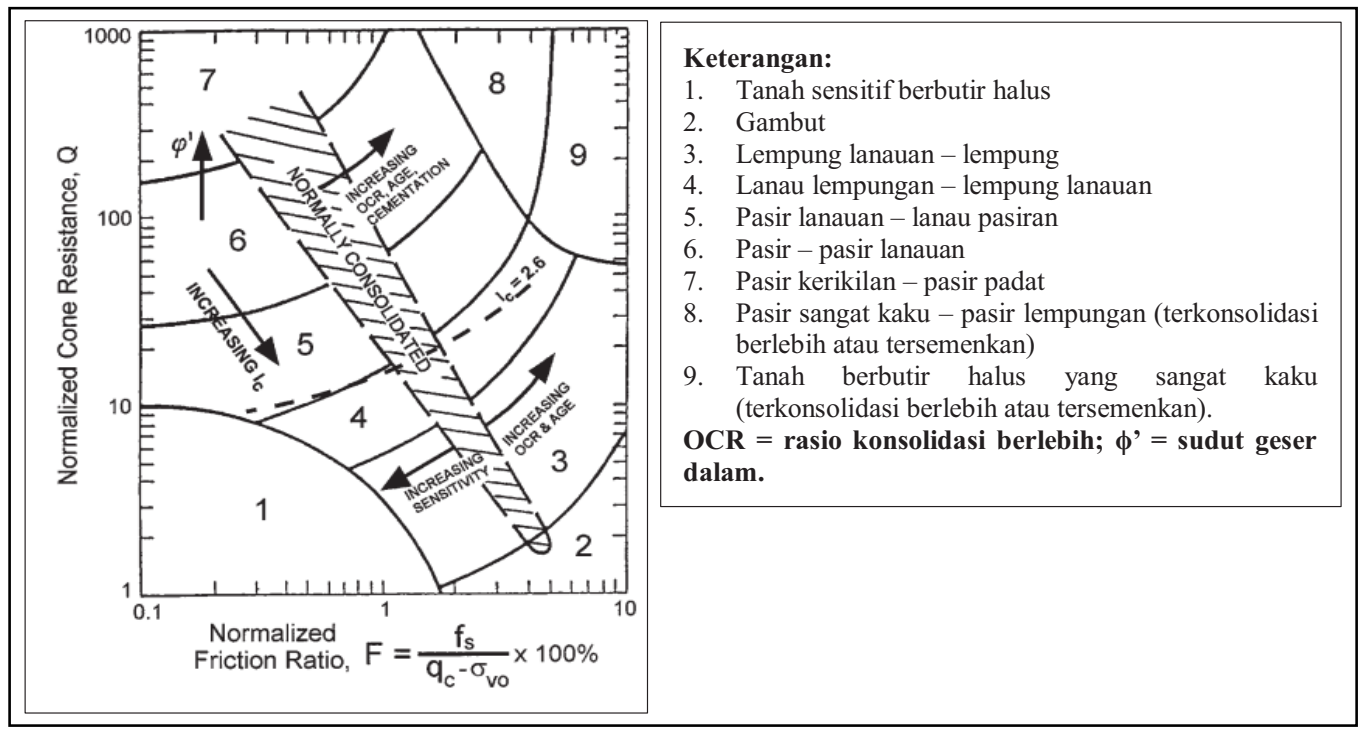

Gambar 5. Grafik indeks perilaku jenis tanah (modifikasi dari Robertson dan Wride, 1998).

\section{METODE PENELITIAN}

Metode yang dilakukan dalam penelitian ini mengacu pada model serta metode penelitian pada endapan sungai dan pantai (delta) seperti Amorosi dan Marchi (1999), Lafuerza drr. (2005), De Mio dan Giacheti (2006), Styllas 
(2014), Iqbal drr. (2016) dan Satriyo (2017). Secara ringkas, metode yang digunakan dalam penelitian ini dibagi menjadi tiga kegiatan, yaitu; pertama, kegiatan di studio untuk mendapatkan gambaran mengenai daerah penelitian dengan memanfaatkan data-data sekunder seperti penelitian terdahulu terkait kondisi geologi dan geologi teknik daerah Indramayu dan sekitarnya semisal peta geologi dan publikasi ilmiah terkait. Acuan yang digunakan akan membantu dalam proses interpretasi geologi bawah permukaan serta karakteristik keteknikan sedimen pada daerah penelitian.

Kedua, kegiatan di lapangan berupa pengamatan hasil pemboran geologi teknik, yakni uji SPT pada 4 titik bor dan uji penetrasi konus (13 titik uji CPT dan 10 titik uji CPTu).

Terakhir, kegiatan di laboratorium seperti analisis besar butir, hidrometer, batas-batas Atterberg (Batas Cair, Batas Plastis dan Indeks Plastisitas), dan klasifikasi USCS untuk mendapatkan parameter sifat fisik dan mekanik tanah. Seluruh uji laboratorium dilakukan di Laboratorium Geomekanika Pusat Geoteknologi LIPI Bandung.

\section{HASIL DAN PEMBAHASAN}

Pengujian laboratorium diambil dari contoh tanah dengan kedalaman yang spesifik ber- dasarkan deskripsi dari hasil pengeboran teknik di 4 titik sebagaimana tertera pada Tabel 3 dan 4. Tabel 3 menunjukkan hasil pengujian laboratorium batas-batas Atterberg terhadap jenis sedimen berbutir halus (lanau dan lempung) yakni batas cair (Liquid Limit/LL), Batas Plastis (Plastic Limit/PL), dan Indeks Plastisitas (Plasticity Index/PI). Tabel 4 menunjukkan variasi nilai N-SPT dan persentase kandungan butir halus (FC) dari setiap contoh pengeboran. Sedimen jenis pasir memiliki FC 10 - 40\%, lanau memiliki tingkat konsistensi sangat lunak sampai keras dengan FC 70 - 99\%, dan lempung memiliki tingkat konsistensi lunak dengan FC $>98 \%$. Sedimen jenis lanau sebagai litologi dominan penyusun daerah penelitian memiliki karakteristik tingkat konsistensi sangat lunak sampai keras dan mengandung banyak pecahan cangkang fauna laut terutama pada titik uji di wilayah utara. Sedimen pasir memiliki karakteristik ukuran butir pasir sangat halus sampai pasir sangat kasar, menyudut tanggung sampai membundar, gradasi baik untuk pasir endapan sungai dan gradasi buruk untuk sedimen endapan pantai, dan tingkat kepadatan sangat lepas sampai sangat padat. Sedimen lempung memiliki karakteristik tingkat konsistensi lunak, sebagian terdapat cangkang fauna laut.

Kegiatan pengukuran menggunakan CPT dilakukan pada 13 titik dan CPTu dilakukan

Tabel 3. Batas-batas Atterberg contoh sedimen berbutir halus (lanau dan lempung) di daerah penelitian

\begin{tabular}{|c|c|c|c|c|}
\hline \multirow{2}{*}{ Kode Bor } & \multirow{2}{*}{ Kedalaman (m) } & \multicolumn{3}{|c|}{ Batas-batas Atterberg (\%) } \\
\hline & & Batas Cair & Batas Plastis & Indeks Plastisitas \\
\hline \multirow{8}{*}{ DH-01 } & $1,50-1,95$ & 98,40 & 42,44 & 55,96 \\
\hline & $3,00-3,45$ & 96,40 & 41,29 & 55,11 \\
\hline & $4,50-4,95$ & 98,25 & 37,59 & 60,66 \\
\hline & $6,00-6,45$ & 95,50 & 42,18 & 53,32 \\
\hline & $7,45-7,95$ & 99,98 & 39,21 & 60,77 \\
\hline & $10,50-10,95$ & 98,20 & 40,18 & 58,02 \\
\hline & $14,00-14,45$ & 96,55 & 45,44 & 51,11 \\
\hline & $17,50-17,95$ & 94,35 & 46,44 & 47,91 \\
\hline \multirow{3}{*}{ DH-02 } & $7,00-7,50$ & 93,37 & 46,76 & 46,61 \\
\hline & $11,00-11,50$ & 82,85 & 28,50 & 54,35 \\
\hline & $15,50-16,00$ & 73,13 & 38,62 & 34,51 \\
\hline \multirow{4}{*}{ DH-03 } & $2,50-3,00$ & 92,56 & 31,09 & 61,47 \\
\hline & $6,00-6,50$ & 93,58 & 40,09 & 53,50 \\
\hline & $12,00-12,50$ & 94,92 & 41,39 & 53,53 \\
\hline & $19,00-19,50$ & 92,88 & 36,3 & 56,58 \\
\hline \multirow{5}{*}{ DH-04 } & $2,00-2,50$ & 58,71 & 27,11 & 31,60 \\
\hline & $2,50-3,00$ & 55,71 & 30,11 & 25,60 \\
\hline & $6,50-7,00$ & 77,65 & 40,17 & 37,48 \\
\hline & $10,80-11,45$ & 86,87 & 38,78 & 48,10 \\
\hline & $15,00-15,65$ & 97,66 & 35,74 & 61,92 \\
\hline
\end{tabular}


Tabel 4. Variasi nilai N-SPT dan persentase kandungan butir halus (FC) contoh sedimen di daerah penelitian.

\begin{tabular}{|c|c|c|c|c|c|}
\hline Kode Bor & Kedalaman (m) & Litologi & N-SPT & Fine Content (\%) & Jenis Sedimen \\
\hline \multirow{7}{*}{ DH-01 } & $1,50-1,95$ & Lanau & 6 & 65,40 & MH \\
\hline & $4,50-4,95$ & Lanau & 18 & 98,39 & MH \\
\hline & $7,45-7,95$ & Lanau & 28 & 98,68 & MH \\
\hline & $9,00-9,45$ & Pasir & 30 & 18,96 & SM \\
\hline & $10,50-10,95$ & Lanau & 29 & 88,72 & MH \\
\hline & $21,00-21,45$ & Pasir & 28 & 23,69 & SM \\
\hline & $24,50-24,95$ & Pasir & 53 & 10,93 & SW-SM \\
\hline \multirow{4}{*}{ DH-02 } & $3,50-4,00$ & Pasir & 4 & 35,04 & SM \\
\hline & $7,00-7,50$ & Lanau & 2 & 95,64 & MH \\
\hline & $11,00-11,50$ & Lanau & 1 & 94,42 & $\mathrm{MH}$ \\
\hline & $15,50-16,00$ & Lanau & 8 & 96,05 & MH \\
\hline DH-03 & $19,00-19,50$ & Lanau & 9 & 99,70 & $\mathrm{MH}$ \\
\hline \multirow{5}{*}{ DH-04 } & $2,00-2,50$ & Lanau & 2 & 94,24 & MH \\
\hline & $2,50-3,00$ & Lanau & 2 & 75,92 & MH \\
\hline & $6,50-7,00$ & Lanau & 2 & 97,68 & MH \\
\hline & $10,80-11,45$ & Lanau & 3 & 99,64 & MH \\
\hline & $15,00-15,65$ & Lanau & 4 & 97,03 & $\mathrm{MH}$ \\
\hline \multicolumn{2}{|c|}{$\begin{array}{l}\text { Keterangan: } \\
\text { SW-SM = Well graded silty sands } \\
\text { SM = Silty sands }\end{array}$} & $\begin{array}{l}\mathbf{M H}=\text { Inorgan } \\
\mathbf{C H}=\text { Inorgani }\end{array}$ & $\begin{array}{l}\text { igh plasti } \\
\text { high plast }\end{array}$ & & \\
\hline
\end{tabular}

pada 10 titik di daerah penelitian yang tersebar memanjang arah selatan-utara dan barat-timur mewakili DAS Cimanuk bagian hilir serta pantai utara Indramayu. Berdasarkan analisis kurva sondir (CPT dan CPTu) di 23 titik lokasi uji, hasil identifikasi kurva sondir menunjukkan adanya tiga lapisan sedimen dengan karakteristik fisik berbeda, yaitu lapisan lempung, lanau, dan pasir. Sedimen berjenis pasir umumnya membentuk pola kurva nilai tahanan konus (qc) bergradasi (menghalus atau mengkasar ke atas), sedangkan berjenis lanau serta lempung cenderung silindris. Interpretasi selanjutnya adalah dengan mengikat data pengeboran teknik dengan pola kurva CPT/CPTu (Gambar 6). Hal tersebut akan membantu korelasi antartitik uji $\mathrm{CPT} / \mathrm{CPTu}$ lainnya, sehingga membantu interpretasi kondisi geologi bawah permukaan daerah penelitian. Gambar 7 menunjukkan penampang geologi bawah permukaan selatanutara dan barat-timur daerah penelitian. Setiap titik uji yang berdekatan dihubungkan untuk memperoleh korelasi geologi bawah permukaan. Hal ini sebagai hasil integrasi data pengeboran teknik dan pola kurva $\mathrm{CPT} / \mathrm{CPTu}$
Berdasarkan hasil uji laboratorium dan pengujian teknik di lapangan, sedimen pasir pada daerah penelitian memiliki karakteristik jenis endapan sungai dan pantai. Pasir endapan sungai memiliki karakteristik ukuran butir pasir kasar sampai sangat halus, berwarna abu-abu kecoklatan, membundar tanggung, memiliki tingkat kepadatan yang padat, non-karbonatan serta bentuk kurva nilai tahanan konus (qc) menghalus ke atas (Styllas, 2014). Pasir endapan pantai memiliki karakteristik ukuran butir pasir sangat kasar sampai sangat halus, berwarna hitam, abu-abu kecoklatan serta coklat, menyudut sampai membundar, memiliki tingkat kepadatan yang lepas sampai sangat padat, karbonatan (mengandung cangkang fauna laut) serta bentuk kurva umumnya mengkasar ke atas atau menghalus ke atas pada fase transgresi (Styllas, 2014). Dalam keadaan jenuh dan terkena efek gempabumi, jenis sedimen pasir yang terendapkan pada lingkungan pantai akan lebih tahan terhadap likuefaksi daripada pasir endapan sungai atau fluvial (Iqbal, 2013). Sedimen pasir pada lingkungan pantai memiliki bentuk butir yang relatif menyudut daripada pasir fluvial. Bentuk 


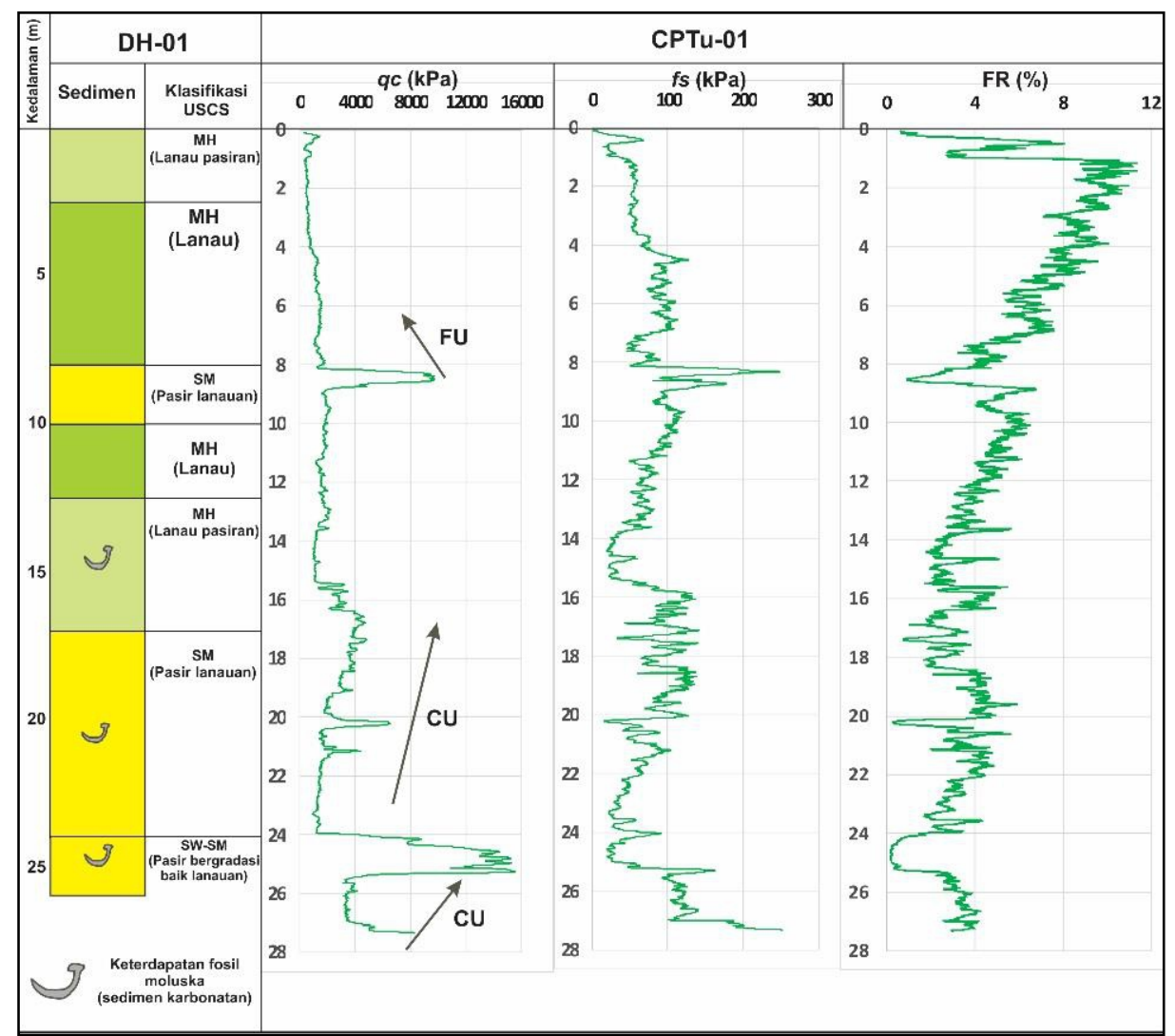

Gambar 6. Integrasi data pengeboran teknik dengan pola kurva CPT/CPTu. Kesebandingan antara pengeboran teknik DH-01 dengan CPTu-01 yang berdekatan akan membantu korelasi geologi bawah permukaan dengan titik uji CPT/CPTu lainnya.

tersebut akan menciptakan kontak antarbutiran yang panjang (long contact), sementara bentuk butir relatif membundar hanya akan menciptakan kontak butiran sebagian sisinya (point contact) (Nichols, 2009). Peristiwa likuefaksi yang terjadi di sedimen pasir pada lingkungan pantai akan berkaitan dengan ukuran butir pasir yang lebih halus, jenis sedimen SP, N-SPT < 20, dan nilai qc $<10 \mathrm{MPa}$ (Iqbal, 2013). Secara umum, likuefaksi berpotensi besar terjadi pada sedimen berumur $<500$ tahun (Youd dan Perkins, 1978), kandungan butir halus (FC) < $20 \%$ (Boulanger dan Idriss, 2014), nilai N-SPT terkoreksi $((\mathrm{N} 1) 60)<30$ (Boulanger dan Idriss, 2014) atau qc $<15 \mathrm{MPa}$ (Shibata dan Taparaska, 1988).

Daerah penelitian, menurut Tjia drr. (1968) serta Bird dan Ongkosongo (1980), merupakan wilayah dengan proses sedimentasi yang cukup aktif terutama bersumber dari Sungai Cimanuk, dengan umur sedimen $<500$ tahun. Dengan demikian, wilayah DAS Cimanuk bagian hilir terutama wilayah utara daerah penelitian berpotensi terhadap likuefaksi karena karakteristik sedimen pasir dan pasiran (endapan pantai) yang masuk dalam kategori tingkat kepadatan lepas berdasarkan nilai uji N-SPT dan CPT/CPTu. Hal ini berbeda dengan jenis sedimen pasir endapan sungai di wilayah selatan daerah penelitian yang tingkat kepadatan relatifnya agak padat sampai padat (DH-01 dan CPTu-03). Hal tersebut memiliki kemiripan dengan hasil penelitian pada wilayah pesisir Indramayu bagian barat (Batu dan Hidayat, 2011), dengan melihat karakteristik sedimen pasir pada titik uji DH-02 dan CPTu07 yang masuk dalam kategori pasir lepas serta jenis sedimen SM (pasir lanauan pada titik uji DH-02).

Amblesan berkaitan dengan tata guna lahan serta karakteristik sedimen yang spesifik akan mempengaruhi besarnya potensi yang terjadi. Wilayah Blanakan (Kabupaten Subang) me- 
Karakteristik Keteknikan Sedimen Kuarter Kaitannya dengan Potensi Bahaya Geologi di Kawasan DAS Cimanuk Bagian Hilir

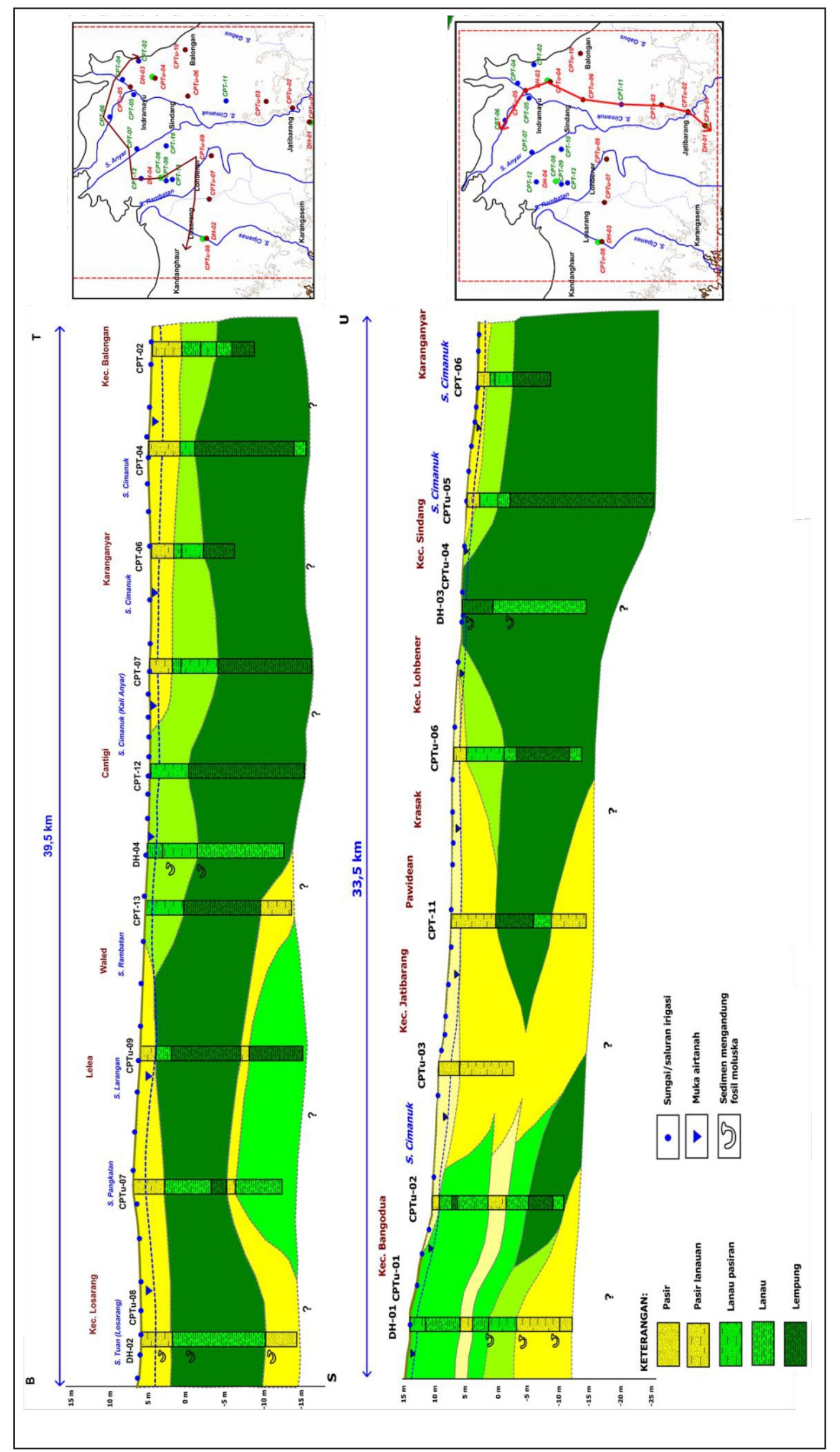

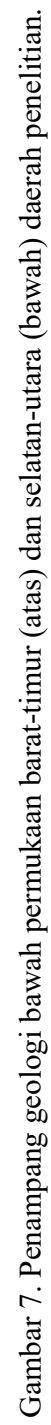


miliki karakteristik sedimen serta tata guna lahan yang mirip dengan wilayah DAS Cimanuk bagian hilir dengan penurunan tanah di wilayah tersebut berkisar antara $6-12 \mathrm{~cm} /$ tahun (Chaussard drr., 2013). Nilai N-SPT $<4$ atau $\mathrm{CPT} / \mathrm{CPTu}<5.000 \mathrm{kPa}$ berpotensi terhadap bahaya amblesan (Soebowo, 2016), sehingga sedimen jenis lanau dan lempung di daerah penelitian berpotensi terhadap timbulnya bahaya geologi tersebut. Pada Tabel 5 dan Gambar 8 ditunjukkan karakteristik keteknikan sedimen Kuarter wilayah DAS Cimanuk bagian hilir serta potensi bahaya geologi yang akan terjadi.

Tabel 5. Karakteristik keteknikan sedimen Kuarter dan potensi bahaya geologi di kawasan DAS Cimanuk bagian hilir

\begin{tabular}{|c|c|c|c|c|c|c|}
\hline Titik uji & Kedalaman (m) & Jenis sedimen & N-SPT & $\begin{array}{c}\text { CPT/CPTu } \\
(\mathrm{kPa})\end{array}$ & $\begin{array}{l}\text { Kepadatan relatif/ } \\
\text { konsistensi }\end{array}$ & Bahaya geologi \\
\hline $\begin{array}{c}\text { DH-01 } \\
\text { CPTu-02 }\end{array}$ & $\begin{array}{l}0-8,5 \\
10-13 \\
\end{array}$ & Lanau dan lanau pasiran & $6-30$ & $450-2.400$ & Sedang - keras & $\begin{array}{c}\text { Amblesan, kecuali } \\
\text { DH-01 }\end{array}$ \\
\hline $\begin{array}{l}\text { CPTu-07 } \\
\text { CPTu-09 }\end{array}$ & $13-21$ & Lanau dan lempung & - & $680-3.200$ & Keras & Amblesan \\
\hline $\begin{array}{c}\text { DH-01 } \\
\text { CPTu-02 } \\
\text { CPTu-03 }\end{array}$ & $\begin{array}{c}8,5-10,5 \\
0-1 ; 9-11 \\
0-4\end{array}$ & Pasir lanauan & 30 & $2.000-13.000$ & Lepas - padat & $\begin{array}{c}\text { Likuefaksi, kecual } \\
\text { DH-01 }\end{array}$ \\
\hline $\begin{array}{c}\text { DH-01 } \\
\text { DH-02 } \\
\text { CPTu-03 } \\
\text { CPTu-05 - } 10 \\
\text { CPT-01 - } 11\end{array}$ & $\begin{array}{c}17,5-26 \\
0-5 ; 16-23 \\
0-12,5 \\
0-6 \\
0-4\end{array}$ & Pasir dan pasir lanauan & $2->53$ & $200-16.000$ & $\begin{array}{c}\text { Sangat lepas - sangat } \\
\text { padat }\end{array}$ & $\begin{array}{l}\text { Likuefaksi, kecual } \\
\text { DH-01 dan CPTu- } \\
03\end{array}$ \\
\hline $\begin{array}{c}\text { DH-01 } \\
\text { DH-04 } \\
\text { CPT-12 dan } 13 \\
\end{array}$ & $\begin{array}{c}10,5-17,5 \\
3-7 \\
0-6\end{array}$ & Lanau pasiran & $1-37$ & $300-4.900$ & Sangat lunak - keras & Amblesan \\
\hline $\begin{array}{c}\text { DH-02 } \\
\text { DH-03 } \\
\text { DH-04 } \\
\text { CPTu-02 } \\
\text { CPTu-04-10 } \\
\text { CPT-01 - } 13\end{array}$ & $\begin{array}{c}5-16 \\
0-20 \\
0-3 \\
13-22 \\
2-22 \\
1,5-20\end{array}$ & Lanau dan lempung & $0-12$ & $200-3.000$ & $\begin{array}{c}\text { Sangat lunak - sangat } \\
\text { kaku }\end{array}$ & Amblesan \\
\hline
\end{tabular}

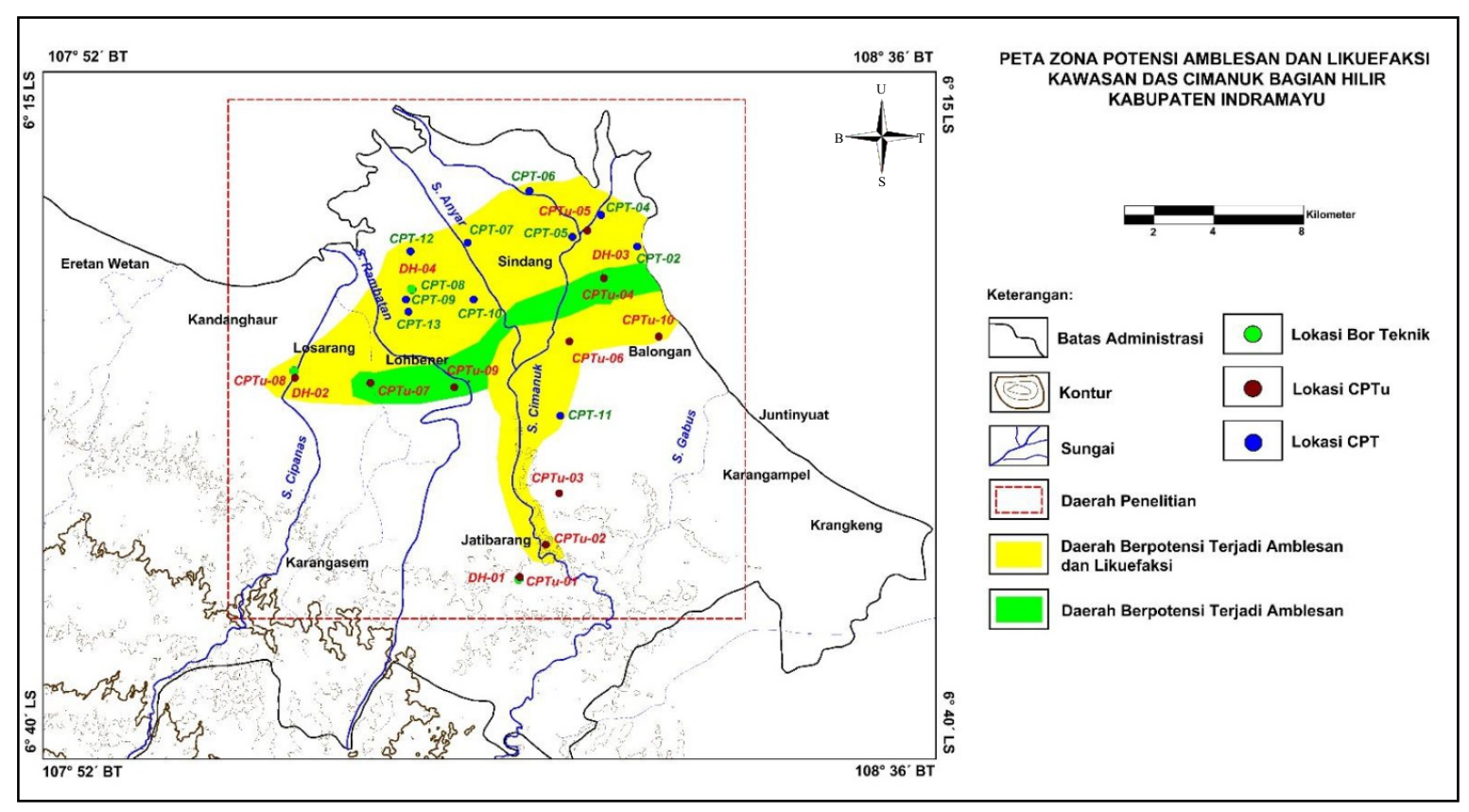

Gambar 8. Peta zona potensi amblesan dan likuefaksi kawasan DAS Cimanuk bagian hilir dan sekitarnya. 


\section{KESIMPULAN}

Hasil analisis geologi dan geologi teknik menunjukkan bahwa secara umum wilayah sepanjang aliran Cimanuk berpotensi terhadap terjadinya bahaya amblesan dan likuefaksi. Karakteristik keteknikan berupa pasir lepas sampai sangat lepas serta lempung dan lanau yang lunak menjadi faktor utama kerentanan daerah penelitian terhadap kedua bahaya geologi tersebut. Dengan demikian, di area sekitar pengujian teknik perlu mendapat perhatian, upaya pengurangan risiko serta mitigasi bahaya amblesan dan likuefaksi, terutama wilayah yang akan dikembangkan menjadi kawasan industri.

\section{UCAPAN TERIMA KASIH}

Penulis mengucapkan terima kasih kepada pihak LPDP Kementrian Keuangan RI atas bantuan dana penelitian, serta Pak Iyuk dan Wahyudin dari Laboratorium Geomekanika, Pusat Geoteknologi LIPI, atas bantuan selama proses analisis laboratorium.

\section{DAFTAR PUSTAKA}

Abidin, H.Z., Andreas, H., Djaja, R., Darmawan, D., dan Gamal, M. 2008. Land subsidence characteristics of Jakarta between 1997 and 2005, as estimated using GPS surveys. Dalam: GPS Solutions, 12(1), 23-32.

Abidin, H. Z., Andreas, H., Gumilar, I., Sidiq, T. P., dan Fukuda, Y. 2013. Land subsidence in coastal city of Semarang (Indonesia): characteristics, impacts and causes. Dalam: Geomatics, Natural Hazards and Risk, 4(3), 226-240.

Achdan, A. dan Sudana, D. 1992. Peta geologi lembar Indramayu, Jawa Barat. Bandung, Badan Geologi.

Akkaya, I., Ozvan, A., Akin, M., Akin, M. K., dan Ovun, U. 2018. Comparison of SPT and Vs-based liquefaction analysis; a case study in Ercis (Van, Turkey). Dalam: Acta Gephysica, 66, 21-38.

Amorosi, A., dan Marchi, N. 1999. High-reso- lution sequence stratigraphy from piezocone tests: an example from the Late Quaternary deposits of the southeastern Po Plain. Dalam: Sedimentary Geology, 128, 67-81.

Andreas, H., Abidin, H.Z., dan Sarsito, D.A. 2017. Tidal inundation ("rob") investigation using time series of high resolution satellite image data and from insitu measurements along northern coast of Java (Pantura). Dalam: $2^{\text {nd }}$ Transdisciplinary Research on Environmental Problems in Southeast Asia, Bandung, M. Sakikabara, A. Saepuloh, I.A. Kurniawan (ed.). IOP Conf. Series: Earth and Environmental Science 71,1-11.

Batu, U. M. L dan Hidayat, S. 2011. Geologi bawah permukaan kaitannya dengan potensi pelulukan likuefaksi di daerah Eretan dan Losarang, Jawa Barat. Dalam: Jurnal Sumber Daya Geologi, 21, 109-124.

Bell, F. G., 2007. Engineering geology (second edition). Butterworth-Heineman, Elsevier Ltd., Jordan Hill, Oxford.

Bird, E. C. F. dan Ongkosongo, O. S. R. 1980. Environmental changes on the coasts of Indonesia. The United Nation University, Tokyo.

Boulanger, R. W. dan Idriss, I. M. 2014. CPT and SPT based liquefaction triggering procedures, Department of Civil and Environtmental Engineering, University of California.

Buana, T. W., Hermawan, W., Rahdiana, R. N., Widyaningrum, R., Wahyudin, Hasibuan, G., Wiyono, dan Sollu, W. P. 2019. Atlas zona kerentanan likuefaksi Indonesia, Badan Geologi, Bandung.

Chaussard, E., Amelung, F., Abidin, H., dan Hong, S. H. 2013. Sinking cities in Indonesia: ALOS PALSAR detects rapid subsidence due to groundwater and gas extraction. Dalam: Remote Sensing and Environment, 128, 150-161.

De Mio, G. dan Giacheti, H. L. 2006, The use of piezocone test for high-resolution stratigraphy of Quartenary sediment squences in the Brazilian coast. Dalam: Annals of The Brazilian Academy of Sciences, 79, 153-170. 
Djuri, M. 1973. Peta geologi lembar Arjawinangun, Jawa Barat. Badan Geologi, Bandung.

Iqbal, P. 2013. Fasies dan karakteristik fisik sedimen Kuarter berpotensi likuefaksi di pesisir Kota Padang dan sekitarnya, provinsi Sumatra Barat. Tesis. Program Magister, Institut Teknologi Bandung.

Iqbal, P., Soebowo. E., Tohari, A., Sadisun, I. A., dan Nugroho, D. 2016. Interpretasi data CPT untuk stratigrafi kuarter resolusi tinggi daerah pesisir Kota Padang, Sumatra Barat. Dalam: Prosiding Geotek Expo Puslit Geoteknologi LIPI, Bandung, Indonesia.

Irsyam, M., Widiyantoro, S., Natawidjaja, D. H., Meilano, I., Rudiyanto, A., Hidayati, S., Triyoso, W., Hanifa, N. R., Djarwadi, D., Faisal, L., dan Sunarjito. 2017. Peta sumber dan bahaya gempa Indonesia tahun 2017. Pusat Penelitian dan Pengembangan Perumahan dan Permukiman, Badan Penelitian dan Pengembangan, Kementerian Pekerjaan Umum dan Perumahan Rakyat Republik Indonesia.

Kurniawan, A. 2011. Evaluasi penurunan muka tanah di wilayah Kota Surabaya dari data pengamatan global positioning system dengan gamit/globk. Tesis Magister. Institut Teknologi Sepuluh Nopember (ITS).

Lafuerza, S., Canals, M., Casamor, J. L., dan Devicienci, J. M. 2005. Characterization of deltaic sediment bodies based on in situ CPT/ CPTU profiles: A case study of the Llobregat delta plain, Barcelona, Spain. Dalam: Marine Geology, Elsevier, 222, 497-510.

Lunne, T., Robertson, P.K. dan Powell, J. J. M. 1997. Cone Penetration Testing in Geotechnical Engineering Practice. Blackie Academic and Professional, New York, USA.

Nichols, G. 2009. Sedimentology and Stratigraphy (2nd edition). John Willey and Sons LtdWilley Blackwell Publishing, Chichester, UK.

Peraturan Pemerintah Republik Indonesia No 14 Tahun 2015. Rencana Induk Pembangunan Industri Nasional Tahun 2015-2035, 6 Maret 2015, Lembaran Negara Republik Indonesia
Tahun 2015 No No 46, Sekretariat Negara, Jakarta.

Robertson, P. K., dan Wride, C. E. 1998. Evaluating cyclic liquefaction potential using the cone penetration test. Dalam: Canadian Geotechnical Journal, 35, 442-459.

Sani, R. A. 2019. Kajian potensi likuefaksi kaitannya dengan perpindahan lateral dan penurunan tanah di kawasan DAS Cimanuk bagian hilir, Kabupaten Indramayu, Provinsi Jawa Barat. Tesis Program Magister. Institut Teknologi Bandung.

Satriyo, A. S. 2017. Analisis karakteristik fisik dan daya dukung sedimen Kuarter di wilayah pesisir Pendungan, Kabupaten Bali Selatan serta kaitannya dengan sebaran fasies. Tesis Program Magister, Institut Teknologi Bandung.

Setyawan, W. B. 2017. Potensi bencana geologi di kawasan delta cimanuk, Kabupaten Indramayu, Jawa Barat. Dalam: Prosiding Seminar Nasional Kelautan XII, Fakultas Teknik dan Ilmu Kelautan Universitas Hang Tuah, Surabaya, Indonesia.

Shibata, T., dan Taparaska, W. 1988. Evaluation of liquefaction potential of soil using cone penetration tests. Dalam: Soils and Foundations, 28, 49-60.

SNI 4153:2008 tentang Cara Uji Penetrasi Lapangan dengan SPT.

Soebowo, E. 2016. Geologi teknik sedimen Kuarter dan bahaya amblesan, likuefaksi di Serangan - Tuban - Tanjung Benoa, Bali. Dalam: Riset Geologi dan Pertambangan, 26, 41-54.

Styllas, M. 2014. A simple approach to define Holocene sequence stratigraphy using borehole and cone penetration test data. Dalam: Sedimentology, 61, 444-460.

Terzaghi, K., Peck, R. B., dan Mesri, G. 1996. Soil mechanics in engineering practice-third edition. John Wiley and Sons, New York, USA. Tjia, H. D., Asikin, S., dan Atmadja, R. S. 1968. Coastal accretion in western Indonesia. Dalam: Bulletin of National Institute of Geology and Mining, 1, 15-45. 
Wesley, L.D. 1977. Mekanika Tanah (cetakan VI). Badan Penerbit Pekerjaan Umum, Indonesia.

Wesley, L. D. 2011. Mekanika Tanah. Penerbit Andi, Yogyakarta, Indonesia.
Youd, T. L., dan Perkins, D. M. 1978. Mapping liquefaction-induced ground failure potential. Dalam: Journal of the Engineering Geotechnical Division, 104, 433-446. 